\title{
Development of Ovarian Tissue Autograft to Restore Ovarian Function: Protocol for a French Multicenter Cohort Study
}

Jean-Baptiste Pretalli ${ }^{1,2^{*}}, \mathrm{PhD}$; Sophie Frontczak Franck ${ }^{2 *}$, MD, MSc; Lionel Pazart ${ }^{1,3}$, MD, PhD; Christophe Roux ${ }^{1,2,4}$, MD, PhD; Clotilde Amiot ${ }^{1,2,4}$, MD, PhD; DATOR Group

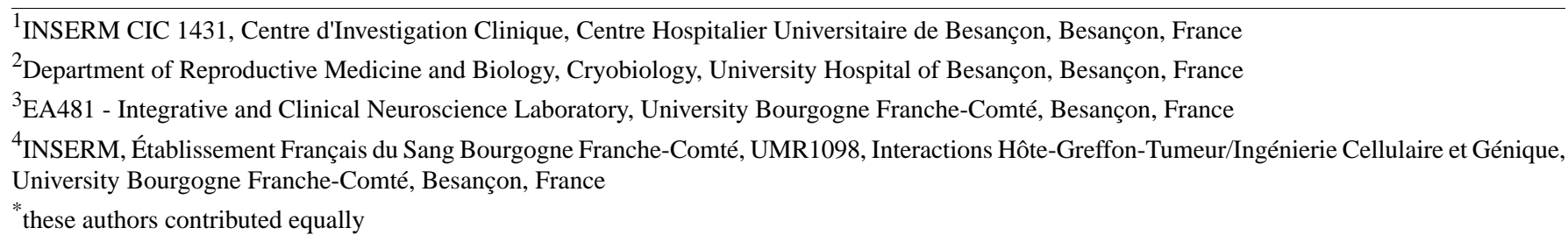

Corresponding Author:

Jean-Baptiste Pretalli, PhD

Department of Reproductive Medicine and Biology, Cryobiology

University Hospital of Besançon

3 boulevard Fleming

Besançon

France

Phone: 33381218127

Email: jbpretalli@chu-besancon.fr

\begin{abstract}
Background: Sterility is a major late effect of radiotherapy and chemotherapy treatments. Iatrogenic sterility is often permanent and greatly impacts long-term quality of life. Ovarian tissue cryopreservation (OTC) performed before gonadotoxic treatments with subsequent autograft is a method of fertility preservation available for girls and women. Its application in prepubertal girls is of particular value as it is the only possible approach in this patient group. In addition, it does not require a delay in cancer therapy and no ovarian stimulation is needed.
\end{abstract}

Objective: The primary aim of this protocol is to help increase the implementation of ovarian tissue autografting in France. Knowledge is still lacking regarding the efficacy of ovarian transplantation in restoring ovarian function and regarding the safety of this procedure, especially the risk of cancer cell reseeding in certain types of cancer. A secondary aim of this study is to generate data to improve our understanding of these two essential aspects.

Methods: The DATOR (Development of Ovarian Tissue Autograft in Order to Restore Ovarian Function) study is ongoing in 17 university hospitals. The DATOR protocol includes the autograft of ovarian cortex fragments. Candidates are identified from an observational prospective cohort (called the Prospective Cohort of Patients Candidates for Ovarian Tissue Autograft [PERIDATOR]) of patients who have undergone OTC. Enrollment in the study is initiated at the patient's request and must be validated by the center's multidisciplinary team and by the study steering committee. The DATOR study begins with a total medical checkup. Ovarian tissue qualification and residual disease detection, if required, are performed.

Results: The study is ongoing. Currently, 38 patients have provided informed consent and have been entered into the DATOR study. Graft has been performed for 34 of these patients. An interim analysis was conducted on the first 25 patients for whom the period of at least 1 year posttransplantation was achieved. Out of these 25 patients, 11 women succeeded in becoming pregnant (pregnancy rate $=44 \%$ [11/25]; delivery rate $=40 \%$ [10/25]). Among these, 6 women conceived twice, and 1 pregnancy led to a miscarriage.

Conclusions: Our preliminary analysis appears to be coherent with the accumulating body of evidence indicating the potential utility of ovarian tissue autograft for patients with premature ovarian failure. All these elements justify the pursuit of our study.

Trial Registration: ClinicalTrials.gov NCT02846064; https://clinicaltrials.gov/ct2/show/NCT02846064

International Registered Report Identifier (IRRID): DERR1-10.2196/12944

(JMIR Res Protoc 2019;8(9):e12944) doi: 10.2196/12944 


\section{KEYWORDS}

cohort study; ovarian tissue; cryopreservation; fertility preservation; pregnancy rate; live birth rate

\section{Introduction}

Cancer is a major public health issue. Its incidence is increasing worldwide, particularly in adolescents and young adults [1-3]. Chemotherapy and/or radiotherapy have significantly improved the chances of long-term survival [4-9]. For women of reproductive age, cancer treatments, particularly those using alkylating agents, and radiation therapy directed at the pelvis or the abdomen can incur the major side effect of inducing premature ovarian failure and infertility [10-16]. The incidence of iatrogenic sterility is consequently increasing [17]. The risk is linked to the patient's age, as well as the type, amount and timing of the treatment delivered $[13,18,19]$.

Mechanisms by which chemotherapies induce damages to ovarian reserve are partially elucidated. Treatments could deplete the primordial follicle pool by direct toxicity to follicles and/or by increasing primordial follicle activation into growing follicles [20]. In cases of pelvic irradiation, preventive surgical measure such as oophoropexy may be indicated. Nonsurgical measures (implying gonadotropin-releasing hormone or luteinizing hormone (LH)-releasing hormone inhibition) designed to minimize gonadotoxic effects might represent alternative strategies, whose efficiency is still controversial [21-28]. Recent studies indicate that primordial follicle activation modulators may provide another promising option for fertility preservation in cancer patients for whom oocyte and embryo cryopreservation are not possible. Nevertheless, they are still under trial [29-31]. A decrease in or loss of fertility is a traumatic issue that greatly impacts long-term quality of life. Several studies have reported the emotional distress of cancer survivors that became sterile [32-34]. Although a spontaneous return of ovarian function and fertility is possible, it occurs in only very few patients $[35,36]$. In this context, most health care providers recognize the importance of fertility preservation measures before the initiation of anticancer drugs. Nevertheless, a very small proportion of patients actually benefit from available fertility preservation procedures [37-44].

Several options can be proposed according to the patients' age, marital status, and pathology. One such fertility preservation technique is ovarian tissue cryopreservation (OTC) $[45,46]$. OTC is independent of ovarian stimulation and can therefore be implemented without delay. In addition, it is the only technique that can be offered to children because neither a partner nor ovarian stimulation with a pickup are required, and it is also suitable for women with hormone-sensitive cancer $[12,47,48]$. Laparoscopic harvesting consists of a total (unilateral) or partial oophorectomy or ovarian tissue biopsies. Ovarian cortex is frozen in fragments $(1 \mathrm{~cm} / 0.5 \mathrm{~cm})$ according to a protocol using slow cooling with manual or automatic seeding $[49,50]$ and then stored in nitrogen gas or liquid. Rapid freezing (vitrification) of ovarian tissue is also possible and might even be more effective than slow freezing [51-53]. Fertile oocytes can be obtained from fragments of cryopreserved ovarian cortex only by maturation of the oocytes present in the primordial, primary, and preantral follicles that have withstood the freezing-thawing process. Various research teams are working on developing in vitro folliculogenesis techniques [54-62] but also autologous transplantation of isolated follicles and subsequent ovarian reconstruction [63-67].

Ovarian tissue autograft is currently the only technique allowing natural restoration of fertility and ovarian endocrine function [68]. Once full cancer recovery is achieved, thawed tissues can be transplanted back into the patient who wishes to have a baby [69]. Ovarian tissue can be transplanted orthotopically (ie, into the pelvic cavity in or near the remaining ovary) or heterotopically (ie, extrapelvically into the forearm or the abdomen for example), the former technique being associated with greater success rates [70-73].

The first ovarian transplantations were reported by Oktay and Karlikaya in 2000 and Radford et al in 2001 [74,75]. These researchers showed a resumption of follicular development, with or without ovarian stimulation. The first human embryo was obtained in vitro in 2004 after heterotopic grafting of subcutaneous ovarian tissue, but its development stopped after its transfer into the uterine cavity [76]. The first live birth after orthotopic autotransplantation of cryopreserved ovarian tissue was described in 2004 by Donnez et al [77]. Ovarian tissue transplantation has since resulted in the birth of more than 130 babies [78,79]. Delivery rates are usually used as an indicator for success, even if not perfectly accurate (there may be more than one transplantation per woman and not every grafted woman had fertility achievement in mind). Delivery rates reported are from $15 \%$ to $50 \%$ [68,79-88].

Predictive factors that would allow the identification of the patients most likely to conceive and safely deliver healthy babies after autotransplantation have not yet been identified. Therefore, there is a need for cohort studies following patients from OTC through to the babies' first months.

In 2009, our team, in collaboration with the university hospital of Limoges (France), reported the first live birth in our country, the seventh in the world. It was the first live birth associated with a noncancerous disorder, namely sickle cell anemia treated by allogeneic bone marrow transplantation [89].

Initially, in France, ovarian tissue preservation was only authorized in the context of research protocols. Then, new legislation on Bioethics (2004) allowed for the practice of germinal tissue preservation in centers accredited by the BioMedicine Agency (Agence de BioMedecine, ABM; decree of December 22, 2006). Worldwide, thousands of patients have benefited from OTC. In France, the ABM reported that 2845 patients had their ovarian tissue cryopreserved by the end of 2016. In France, the 2008 decree relative to the rules for good clinical and biological practices for medically assisted procreation stipulates that the use of germinal tissue must remain in the field of research. A further decree published in 2017 requires that specific information on the knowledge and results generated by any research protocols must be delivered [90]. 
Only 3 research protocols are currently recruiting patients in our country with the aim of proposing transplantation of cryopreserved ovarian cortex in women with premature ovarian failure. One of those protocols, named CAROLéLISA (Autograft of Human Ovarian Tissue: Efficiency and Safety), is led by Professor Catherine Poirot in the unit of reproduction biology of Assistance Publique-Hôpitaux de Paris in Paris. The first patient was included in June 2010 and the cohort currently comprises 40 subjects. Professor Bruno Salle and Dr Jacqueline Lornage are leading a protocol in the university hospital Lyon-Bron, Lyon, but no details of the study procedures are available.

The DATOR study (Development of Ovarian Tissue Autograft in Order to Restore Ovarian Function) (NCT02846064) was launched in 2013 with the aims of assessing the safety and efficacy of ovarian tissue autotransplantation in terms of restoration of ovarian function and fertility. This evaluation will take into account graft survival in the short-to-medium term.

\section{Methods}

\section{Design and Objectives}

The DATOR study is a multicenter prospective longitudinal cohort project. Candidates for the DATOR study are identified from an observational prospective cohort (named Prospective Cohort of Patients Candidates for Ovarian Tissue Autograft [PERIDATOR]) of patients who have undergone OTC. The PERIDATOR cohort specifically aims to record the number and describe the profile of patients who have undergone OTC in the participating hospitals. The DATOR study allows the dissemination of the orthotopic 2-step surgical technique in France, thus making it available to a greater number of patients.

\section{Participants}

The DATOR protocol was initially conducted in 12 French university hospitals, and a total of 17 centers are now recruiting (Besançon, Limoges, Toulouse, Rouen, Bordeaux, Clermont-Ferrand, Strasbourg, Clamart, Nantes, Marseille, Lille, Reims, Bondy, Grenoble, Nancy, Tenon, and Poissy). In each center, each case is discussed within a multidisciplinary team including biologists, surgeons, gynecologists, hematologists, oncologists, pathologists, endocrinologists, and/or pediatricians.

\section{Study Size}

After a preliminary survey of the 12 centers that were among the first to participate, the number of patients eligible was estimated at 186 , out of a total of 650 cryopreservations performed in those centers at that time. Recruitment began in 2013.

Regarding the DATOR study, an authorization was originally obtained for 10 transplantations over a 2-year period. A first protocol modification extended the number of grafts allowed to 20. Two 24-month extensions of the inclusion period were granted in 2017 and in 2018. Therefore, the inclusion period now extends from 2013 to 2021 with a 3-year follow-up to achieve 62 ovarian transplantations.

\section{Recruitment}

The inclusion criteria for both the PERIDATOR cohort and the DATOR study are as follows: women between 18 and 43 years of age, who underwent ovarian tissue cryopreservation, and cured of their primary disease.

Specific inclusion criteria for the PERIDATOR cohort are as follows: short- or medium-term childbearing desire and premature ovarian failure documented by ultrasound criteria (antral follicle counts <5) and hormonal criteria (anti-Müllerian hormone $[\mathrm{AMH}]<2 \mathrm{ng} / \mathrm{mL}$, even if follicle-stimulating hormone $[\mathrm{FSH}]<20 \mathrm{IU} / \mathrm{L})$.

Specific inclusion criteria for the DATOR study are as follows: short-term childbearing desire; total premature ovarian failure defined, in the absence of hormone therapy, by the association of suggestive clinical criteria (secondary amenorrhea, flushes, signs of estrogen deficiency, etc), ultrasound criteria (absence of antral follicle), and hormonal criteria: FSH > $20 \mathrm{IU} / \mathrm{L}, \mathrm{AMH}$ $<2 \mathrm{ng} / \mathrm{mL}$, and low estradiol level; and patients included retrospectively, that is, patients who have already undergone ovarian tissue autograft.

Exclusion criterion is patients under legal protection.

\section{Inclusion in the Development of Ovarian Tissue Autograft in Order to Restore Ovarian Function Study}

Patient included in the PERIDATOR cohort are followed up annually after OTC and after the end of the gonadotoxic therapy (clinical, hormonal, and ultrasound workup with the biologists and gynecologists in the treating center). Adult patients who wish to conceive a child can make a request to undergo ovarian tissue autograft. Participation in the DATOR study is then proposed, and if the patient accepts, then the case is discussed in the multidisciplinary meeting in the treating center.

\section{Pretransplantation Workup and Biological Qualification of the Grafts}

The clinical examination includes the search for clinical signs of primary ovarian insufficiency (absence of menstrual cycles and hot flushes). The administration (or not) of hormone replacement therapy is recorded. The mandatory blood tests required for medically assisted procreation as well as hormone tests (FSH, LH, AMH, inhibin B, and estradiol) are performed. Pelvic ultrasound with Doppler is performed to assess the size of the uterus and the remaining ovary (-ies) and the thickness of the endometrium under hormone replacement therapy. Finally, a preoperative consultation with an anesthesiologist is also performed.

To complete the pretransplant workup, biological qualification of the grafts is performed. One of the fragments of cryopreserved ovarian tissue, selected at random, is thawed according to the protocol validated for the actual transplant. The majority of the thawed fragment is then prepared for pathological examination, and the remainder is used to evaluate the long-term viability of the isolated ovarian follicles. The pathology exam evaluates the quality of the tissue after the freeze-thaw cycle and the abundance of follicles, and it also investigates the presence of any potential anomalies, in particular the presence of residual malignant cells in cases where the initial pathology was cancer. 
If the number and quality of follicles are found to be low, then the number of fragments of ovarian cortex to be used for the autograft can be increased. Microbiological controls are performed on the freezing, thawing, and transport media of the fragment under investigation.

The possible reseeding of malignant cells during the autograft of ovarian fragments is a problem of great importance. Acute leukemia is the most common childhood cancer. Performing autotransplantation on patients at high risk of cancer reseeding (ie, acute leukemia) is not recommended because of the high risk of cancer cell reintroduction [91,92]. The clinical decision requires the use of minimal residual disease detection techniques, molecular analysis [93-95], flow cytometry [96,97], and xenograft $[98,99]$.

\section{Decision of the Steering Committee}

The local investigating centers put together a file that is subsequently submitted to the steering committee of the DATOR study. The steering committee is composed of experts from the multidisciplinary teams of various university hospitals in France. The steering committee evaluates the rational for the autograft, and the risk-benefit ratio (quality of the preserved fragments, obstetrical risk, and cancer risk). The steering committee may call on outside experts, if necessary. The decision of the steering committee takes account of the progress in techniques that make it possible to assess residual disease in the ovaries. After evaluation of the file, the steering committee approves (or does not approve) the ovarian transplantation.

\section{Development of Ovarian Tissue Autograft in Order to Restore Ovarian Function Protocol}

\section{Graft Thawing and Preparation}

The freezing and thawing protocol for ovarian tissue has previously been described and established in the laboratory [89]. The thawing of the ovarian fragments is carried out sterilely in class A, under a hood, in the laboratory of the assisted reproductive technology (ART) center. After quickly thawing the vials, the strips are washed in decreasing solutions of DMSO $1.5 \mathrm{M}$ (5 min), $1 \mathrm{M}$ (5 min), $0.5 \mathrm{M}$ (10 min), and $0.05 \mathrm{~mol} / \mathrm{L}$ sucrose in Leibovitz L-15 medium supplemented with $10 \%$ decomplemented patient serum. The strips are then rinsed and transferred to the operating theater for the graft in medium containing $20 \%$ serum only.

Regarding the second step of the transplantation, if the size of the fragments of ovarian cortex is less than $0.5 \mathrm{~cm}^{2}$, several fragments can be sutured in an ovarian patch of $2 \mathrm{~cm}^{2}$ by the surgeon in the laboratory under a laminar flow hood.

\section{Autograft}

Surgeons from each of the centers participating in the study have been trained in the autograft technique for the implantation of cryopreserved ovarian tissue by Dr Pascal Piver who proctored the first autografts in all centers.
The 2-stage orthotopic graft is the first-line technique used in this study [89]. The transplantation is performed in 2 stages by celioscopy under general anesthesia. It can also be performed with the aid of a surgical robot in centers equipped with such facilities and who are trained in its use. Heterotopic transplantation can be proposed if a contraindication exists to orthotopic transplantation.

\section{Follow-Up in the Development of Ovarian Tissue Autograft in Order to Restore Ovarian Function Study}

To collect outcome data to evaluate the success of the autograft, monthly follow-up is performed for 1 year after the transplant or until the patient becomes pregnant. The monthly follow-up includes clinical, biological, and ultrasound examination. The clinical evaluation is performed by the gynecologists and biologists of the ART unit in the participating center. They investigate for clinical signs of recovery of ovarian function (onset of spontaneous menstrual cycles or disappearance of hot flushes). Biological follow-up includes hormone tests (FSH, $\mathrm{LH}, \mathrm{AMH}$, inhibin $\mathrm{B}$, estradiol, and progesterone). Normalization of endogenous gonadotropins is also investigated. While awaiting this stage, hormone replacement therapy and administration of vitamin are pursued.

Echographic follow-up comprises transvaginal ultrasound of the grafts (presence of antral follicles) associated with Doppler examination to evaluate neovascularization. Magnetic resonance imaging is performed 3 months after the transplantation to assess the state of revascularization of the grafts and to determine the origin of neovascularization.

As soon as ovary function is recovered, either by normalization of gonadotropins, with or without elevation of $\mathrm{AMH}$, or by the appearance of echographic signs, monitoring of folliculogenesis and ovulation is implemented at each cycle, with a view to achieving pregnancy by scheduled intercourse, with or without ovulation-stimulating treatment. In case of failure, an appropriate ART technique is implemented (intrauterine insemination or in vitro fertilization with or without intracytoplasmic sperm injection).

Monthly follow-up can be discontinued 1 year after the transplantation if the ovarian function has not recovered. In this case, the transplant is considered to have failed. In this situation, a further transplant attempt with the remaining cryopreserved fragments can be proposed with the approval of the steering committee.

Finally, if the patient becomes pregnant, follow-up is completed by a search for any complications during pregnancy and delivery, and the baby's development is followed up to 3 months after the birth.

The study flowchart is presented in Figure 1. 
Figure 1. Study flowchart.

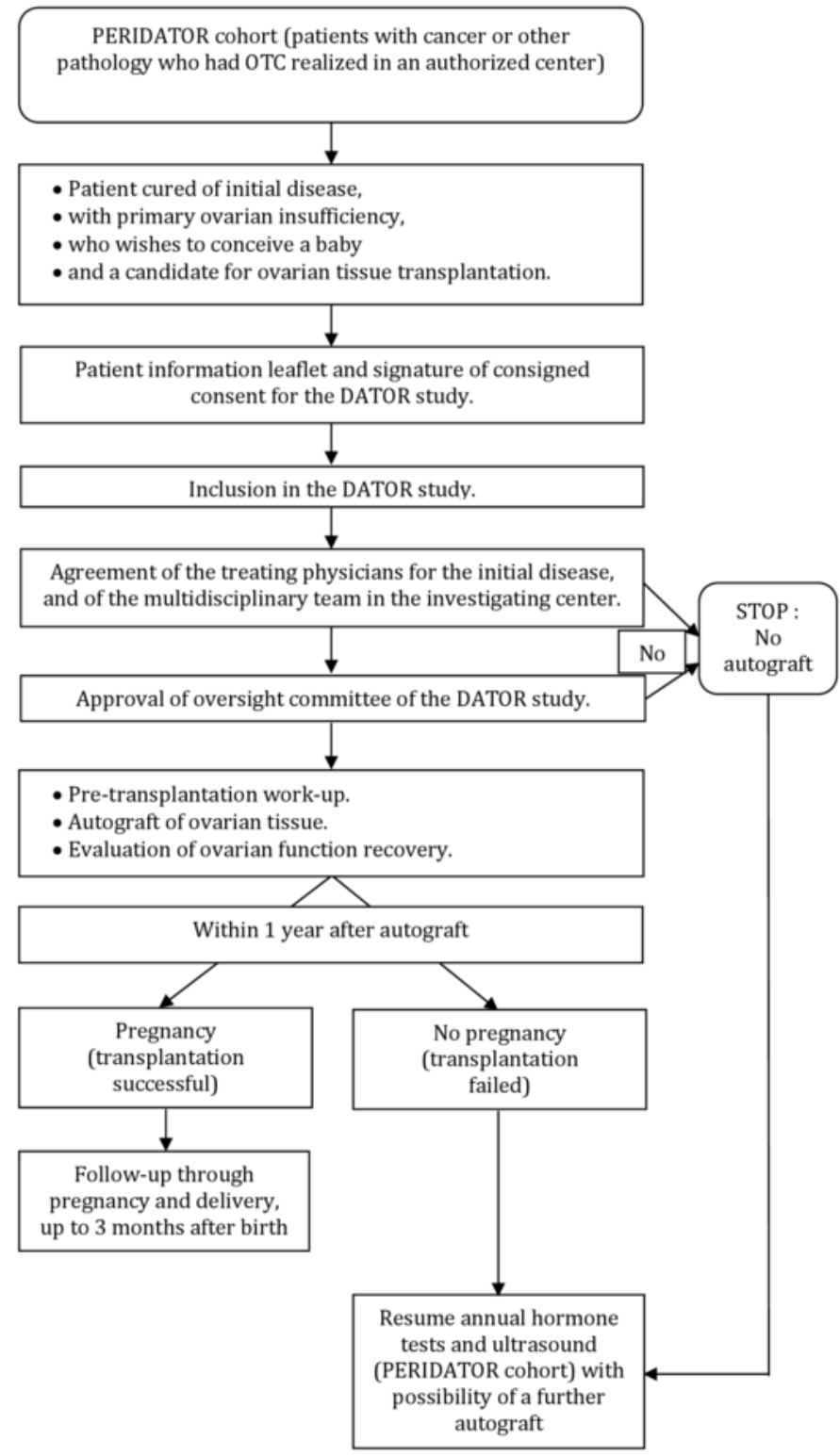

\section{Data Analyzed}

\section{Primary Outcome}

Patients will be dichotomized into 2 groups. The restored group will comprise patients who achieve ovarian function restoration evidenced by the onset of a pregnancy. The not restored group will comprise patients who do not achieve ovarian function restoration. Fertility restoration is defined as the occurrence of a pregnancy leading or not leading to a live birth.

\section{Secondary Outcomes}

The secondary outcomes are as follows: number of live births after ovarian tissue autograft, number of complications that could result from a surgery with anesthesia or depending on graft quality, number of graft recovery, and number of residual disease development.

The information obtained with this study will contribute to our knowledge on autologous ovarian tissue transplantation, the preservation of ovarian function, and the reuse of self-preserved ovarian tissue to be improved. Advances are also expected in the management of patients.

This protocol will allow the surgical teams of the participating centers to be trained in the practice of the autograft of ovarian cortex, especially the 2 -stage grafting technique codified by Limoges' team.

\section{Data Collection and Research Measures}

Data pertaining to all patients will be rendered anonymous before being centralized at the coordinating center in Besancon, where they will be verified and completed (if necessary) and entered into a secure database. All study documentation will be conserved in a locked office.

\section{Statistical Methods}

An interim analysis was planned on the first 25 patients who arrived at 1 year after transplantation. The objective was to check that the results were sufficiently favorable to allow continuation and extension of the study. 
All analyses will be performed using SAS version 9.4 (SAS Institute Inc). Continuous variables will be presented as mean (SD) and median (interquartile range). Categorical variables will be presented as number and percentage.

Some potential prognostic factors will be measured at baseline and will be compared between the not restored fertility and restored fertility groups using the Pearson chi-square test or Fisher exact test for categorical variables and the Student $t$ test or analysis of variance for normally distributed quantitative variables. The Mann-Whitney U and Kruskal-Wallis tests will be used for comparison of nonnormally distributed variables and semiquantitative variables. Multivariate analysis (logistic or Cox regression) will be used if we have a sufficient power for this analysis. A $P$ value of less than .05 will be considered statistically significant.

\section{Ethics and Dissemination}

This study is conducted in agreement with the Declaration of Helsinki (amended in October 2013). Before study initiation, the protocol and informed consent document were submitted to the ethical review committee of Franche-Comté and to the French National Agency for the Safety of Health Products (Agence nationale de sécurité des médicaments et des produits de santé), both of which gave their approval. Signed informed consent is obtained from all participating patients. Patient anonymity is protected by the use of subject identification codes.

Clinical follow-up is provided by physicians and surgeons. The risks associated with ovarian tissue transplantation are the risks related to laparoscopy and general anesthesia. No drugs other than those normally prescribed in daily medical practice are used.

The findings from this study will be disseminated at several regional and international research conferences and as published articles in peer-reviewed journals.

The trial is registered with Clinicaltrials.gov under the number NCT02846064.

\section{Results}

\section{Project Progress}

Recruitment is ongoing. A total of 142 patients have been included in the PERIDATOR cohort (data as of December 31, 2018), and 38 patients are now cured of the initial disease and have provided written consent to enter the DATOR study. Transplantation has been performed in 34 of them. The flowchart of the preliminary analysis is presented in Figure 2.

Figure 2. Flowchart of the preliminary analysis. DATOR: Development of Ovarian Tissue Autograft in Order to Restore Ovarian Function.

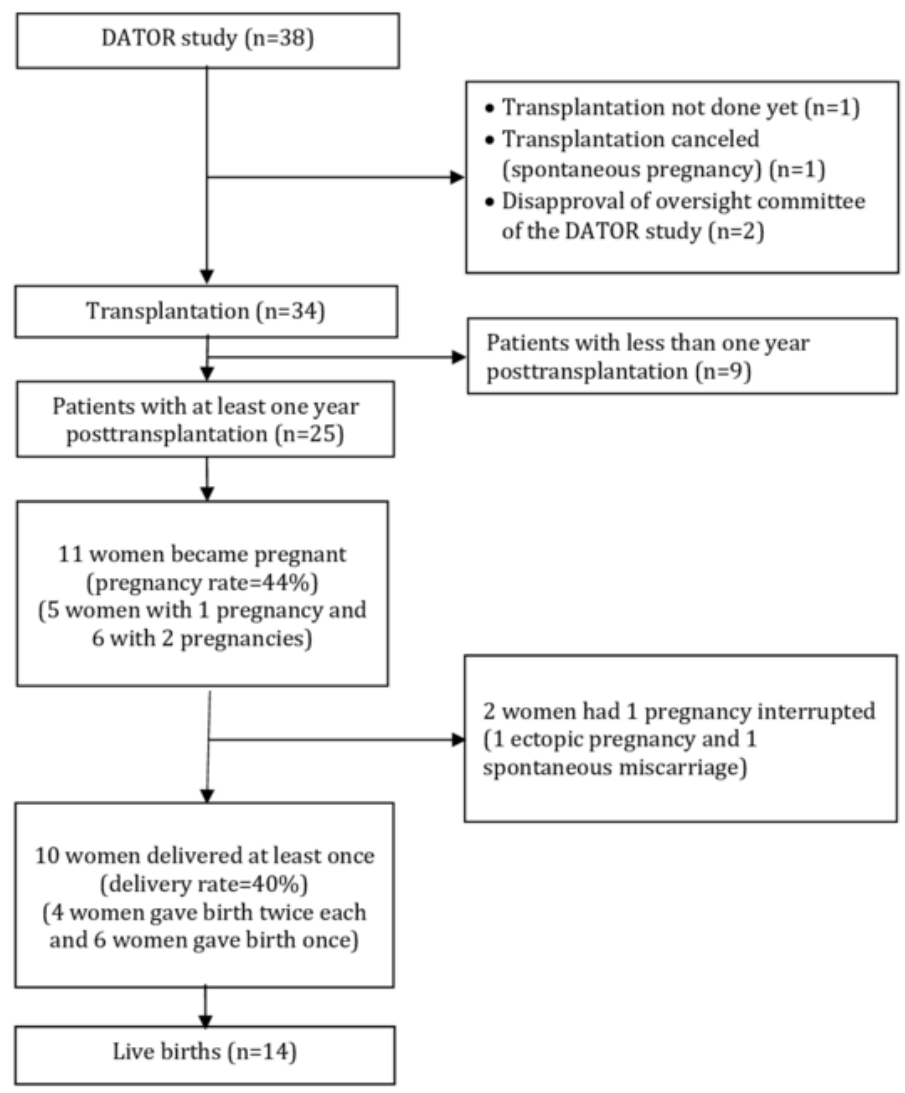

\section{Preliminary Analysis}

An interim analysis was planned on the first 25 patients for whom the period of at least 1 year post transplantation was achieved. Among these 25 patients, 11 women succeeded in becoming pregnant (pregnancy rate $=44 \%$ ). In addition, 10 women gave birth to 14 babies, 4 of them conceived twice (delivery rate $=40 \%$ ), and two-third $(11 / 17)$ of them resulted from natural conception. The average time to conception was 11.3 (SD 6.3) months, with a minimum of 5.7 months and a maximum of 25.5 months. 
Patients' characteristics and outcomes of transplantation are presented in Tables 1 and 2. No heterotopic transplantation was performed.

Menses returned spontaneously in $68 \%$ of the patients $(n=14)$, on average 5.4 months (SD 2.3) after ovarian tissue autograft ( minimum $=2$, maximum $=93 ; n=22$ ). Antral follicles were found in 20 patients of the 21 patients $(95 \%)$ for whom data were available. The first antral follicle appeared on average 3.7 months (SD 2.2) after ovarian tissue autograft (minimum=1, maximum=10). From the onset of the first antral follicle in ultrasound, the mean count of antral follicles was 3 (SD 1.6; minimum=1, maximum=8).

The global mean FSH after autotransplantation was 50.1 UI/L (SD 26.7; $\mathrm{n}=23$; minimum=8.2, maximum $=133$ ) for all patients, $55 \mathrm{UI} / \mathrm{L}(\mathrm{SD} 32.5 ; \mathrm{n}=14$; minimum=8.2, maximum=133) for the no pregnancy group and $41 \mathrm{UI} / \mathrm{L}$ (SD 9.9; $\mathrm{n}=9$; minimum=32, maximum=65) for the pregnancy group, without significant difference. However, a progressive decrease in FSH was observable for the pregnancy group at the beginning of the follow-up and more particularly from the third month until falling below the threshold of $20 \mathrm{IU} / \mathrm{L}$ on average in the sixth month of follow-up Figure 3.

During the follow-up, AMH was undetectable for 10 patients, detectable for 12 , and missing for 3 . When positive, on average 3.4 months (SD 0.2) after autograft, the mean level of AMH was $0.3 \mathrm{ng} / \mathrm{mL}$ (minimum=0.01, maximum=0.77).

Procedures for the detection and recording of adverse events were implemented. No serious adverse event relating to transplantation and no residual disease reseeding was reported. All babies were born healthy.

Table 1. Demographic and clinical characteristics.

\begin{tabular}{|c|c|c|c|c|}
\hline Variables & No pregnancy & Pregnancy & Total & $P$ value \\
\hline Patient, n (\%) & $14(56)$ & $11(44)$ & $25(100)$ & $\mathrm{N} / \mathrm{A}^{\mathrm{a}}$ \\
\hline \multicolumn{5}{|l|}{ Initial disease, $n(\%)$} \\
\hline Hodgkin lymphoma & $11(79)$ & $6(55)$ & $17(68)$ & N/A \\
\hline Non-Hodgkin lymphoma & $1(7)$ & $2(18)$ & $3(12)$ & N/A \\
\hline Ewing sarcoma & $0(0)$ & $1(9)$ & $1(4)$ & N/A \\
\hline Periarteritis nodosa & $0(0)$ & $1(9)$ & $1(4)$ & N/A \\
\hline Systemic mastocytosis & $1(7)$ & $0(0)$ & $1(4)$ & N/A \\
\hline Sickle cell disease & $0(0)$ & $1(9)$ & $1(4)$ & N/A \\
\hline Neurolupus & $1(7)$ & $0(0)$ & $1(4)$ & N/A \\
\hline Gonadotoxic treatment before ovarian tissue cryopreservation, $\mathrm{n}(\%)$ & $12(67)$ & $6(33)$ & $18(100)$ & .99 \\
\hline Age at cryopreservation (years), mean (SD) & $26.2(4.6)$ & $26.7(3.8)$ & $26.4(4.2)$ & .89 \\
\hline Age at transplantation (years), mean (SD) & $33.6(3.9)$ & $31.6(4.9)$ & $32.8(4.3)$ & .81 \\
\hline Storage duration (years), mean (SD) & $6.7(2.5)$ & $5.9(3.2)$ & $6.4(2.8)$ & .29 \\
\hline Number of grafted fragments, mean (SD) & $13(2.6)$ & $11.6(4.6)$ & $12(3)$ & .56 \\
\hline Follicular density $/ \mathrm{mm}^{2}$, mean (SD) & $4.9(5.2)$ & $5(5.1)$ & $5(4.7)$ & .97 \\
\hline Time to conception (months), mean (SD) & N/A & $11.3(6.3)$ & N/A & N/A \\
\hline Follicle-stimulating hormone levels (mUI/mL), mean (SD) & $79(24.8)$ & $86.9(30.4)$ & $82.5(27.1)$ & .43 \\
\hline Anti-Müllerian hormone levels (ng/mL), mean (SD) & $0.08(0.15)$ & $0.03(0.09)$ & $0.06(0.13)$ & .52 \\
\hline Age at conception, mean (SD) & N/A & $33.9(5.2)$ & N/A & N/A \\
\hline Live births, $\mathrm{n}$ & N/A & 14 & 14 & N/A \\
\hline
\end{tabular}

${ }^{\mathrm{a}} \mathrm{N} / \mathrm{A}$ : not available. 
Table 2. Detailed patient characteristics and outcomes of transplantation.

\begin{tabular}{|c|c|c|c|c|c|c|c|c|}
\hline $\begin{array}{l}\text { Patient } \\
\text { number }\end{array}$ & Initial disease & $\begin{array}{l}\text { Treatment before } \\
\text { ovarian tissue } \\
\text { cryopreservation }\end{array}$ & $\begin{array}{l}\text { Age at } \\
\text { grafting } \\
\text { (years) }\end{array}$ & $\begin{array}{l}\text { Assisted reproductive } \\
\text { technology }\end{array}$ & Pregnancy & $\begin{array}{l}\text { Weeks of } \\
\text { amenorrhea }\end{array}$ & Outcome & $\begin{array}{l}\text { Age at conception } \\
\text { (years) }\end{array}$ \\
\hline 1 & Polyarteritis nodosa & Yes & 35.6 & Yes & Yes & $\mathrm{N} / \mathrm{A}^{\mathrm{a}}$ & $\begin{array}{l}\text { Ectopic } \\
\text { pregnancy }\end{array}$ & 36.8 \\
\hline 1 & Polyarteritis nodosa & Yes & 35.6 & Yes & Yes & 36.6 & Live birth & 36.1 \\
\hline 2 & Sickle cell disease & No & 22.5 & No & Yes & 38 & Live birth & 27.4 \\
\hline 2 & Sickle cell disease & No & 22.5 & No & Yes & 36 & Live birth & 29.8 \\
\hline 3 & Hodgkin lymphoma & Yes & 31.6 & Yes & Yes & 37.9 & Live birth & 32.2 \\
\hline 4 & Hodgkin lymphoma & Yes & 26.3 & No & Yes & 40.1 & Live birth & 27.7 \\
\hline 4 & Hodgkin lymphoma & Yes & 26.3 & No & Yes & 40.3 & Live birth & 30.6 \\
\hline 5 & Hodgkin lymphoma & Yes & 37.9 & $-\mathrm{b}$ & No & N/A & N/A & N/A \\
\hline 6 & Hodgkin lymphoma & No & 33.2 & Yes & No & N/A & - & N/A \\
\hline 7 & $\begin{array}{l}\text { Non-Hodgkin lym- } \\
\text { phoma }\end{array}$ & Yes & 31 & No & Yes & 39 & Live birth & 33.1 \\
\hline 8 & Ewing sarcoma & No & 32.4 & No & Yes & 41 & Live birth & 33.5 \\
\hline 8 & Ewing sarcoma & No & 32.4 & No & Yes & 40.5 & Live birth & - \\
\hline 9 & Hodgkin lymphoma & Yes & 43 & Yes & Yes & N/A & $\begin{array}{l}\text { Miscar- } \\
\text { riage }\end{array}$ & 44.5 \\
\hline 10 & $\begin{array}{l}\text { Non-Hodgkin lym- } \\
\text { phoma }\end{array}$ & Yes & 30.8 & Yes & No & N/A & N/A & N/A \\
\hline 11 & Hodgkin lymphoma & Yes & 27.6 & Yes & No & N/A & N/A & N/A \\
\hline 12 & Mastocytosis & No & 37.2 & Yes & No & N/A & N/A & N/A \\
\hline 13 & Hodgkin lymphoma & No & 38.9 & Yes & No & N/A & N/A & N/A \\
\hline 14 & Hodgkin lymphoma & No & 37.4 & Yes & Yes & 38.1 & Live birth & 38 \\
\hline 14 & Hodgkin lymphoma & No & 37.4 & No & Yes & - & Live birth & - \\
\hline 15 & Hodgkin lymphoma & Yes & 31.3 & - & No & N/A & N/A & N/A \\
\hline 16 & Hodgkin lymphoma & Yes & 27.2 & Yes & No & N/A & N/A & N/A \\
\hline 17 & Hodgkin lymphoma & Yes & 28.8 & No & Yes & 42 & Live Birth & 29.4 \\
\hline 18 & Hodgkin lymphoma & No & 30.9 & No & Yes & 41 & Live Birth & 31.4 \\
\hline 19 & Hodgkin lymphoma & Yes & 34.7 & - & No & N/A & N/A & N/A \\
\hline 20 & Neurological lupus & Yes & 35.4 & - & No & N/A & N/A & N/A \\
\hline 21 & Hodgkin lymphoma & No & 35.6 & No & Yes & 41 & Live birth & 36.5 \\
\hline 21 & Hodgkin lymphoma & No & 35.6 & No & Yes & N/A & $\begin{array}{l}\text { Ongoing } \\
\text { pregnancy }\end{array}$ & N/A \\
\hline 22 & Hodgkin lymphoma & Yes & 30.1 & Yes & No & N/A & N/A & N/A \\
\hline 23 & Hodgkin lymphoma & No & 34.1 & - & No & N/A & N/A & N/A \\
\hline 24 & Hodgkin lymphoma & Yes & 34.8 & - & No & N/A & N/A & N/A \\
\hline 25 & Hodgkin lymphoma & Yes & 27.3 & - & No & N/A & N/A & N/A \\
\hline
\end{tabular}

${ }^{\mathrm{a}} \mathrm{N} / \mathrm{A}$ : not appliciable.

${ }^{\mathrm{b}}$ Not available. 
Figure 3. Box plots of monthly follicle-stimulating hormone levels during the year after autograft for the no pregnancy (blue) and the pregnancy group (red). For each group, the curves represent the monthly follicle-stimulating hormone means for the no pregnancy (blue curve) and for the pregnancy group (red curve), respectively. FSH: follicle-stimulating hormone.

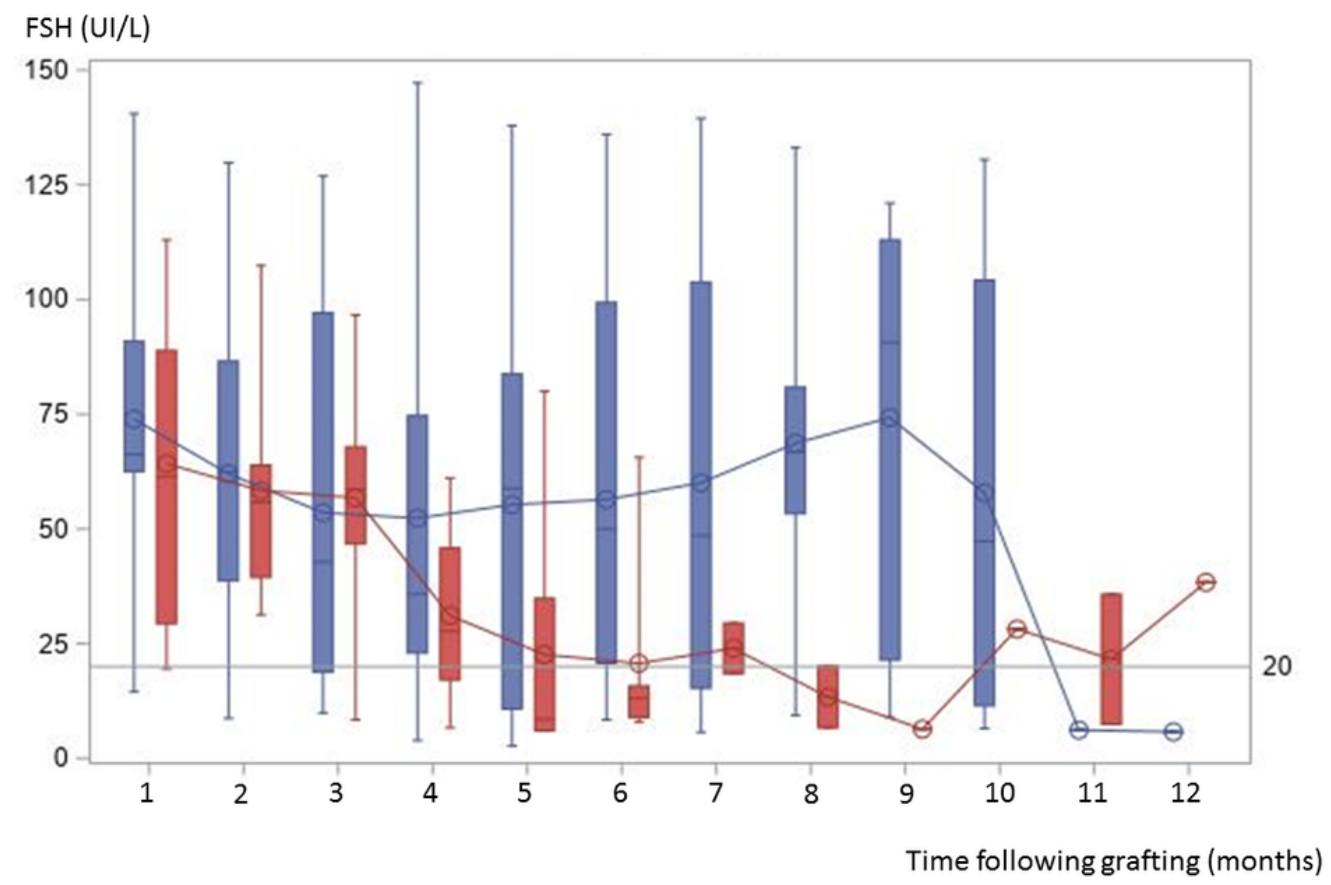

\section{Discussion}

\section{Principal Findings}

According to the literature, OTC with subsequent autotransplantation provides a natural means of fertility restoration and is the only technique that can be offered to prepubertal girls [68]. For some authors, given the number of live births and ongoing pregnancies described to date, this fertility preservation method may now be considered as established [45,91]. In France, the publication of the decree dated 2008 pertaining to the rules of good clinical and biological practice for medically assisted procreation stipulates that the subsequent use of germinal tissue must remain in the field of research [100]. The publication of the June 30, 2017, decree demands that information on the state of knowledge and the results of any existing research protocols be delivered [90]. In France, the current DATOR study is one of 3 ongoing research protocols enabling the autograft of human ovarian tissue. The DATOR study is a warranty for patients as it enables wider availability of the practice of ovarian cortex autograft, notably the 2-stage grafting technique codified by Dr Pascal Piver (of the team in Limoges), by training the surgical teams in the participating centers. In addition, every case is evaluated by a multidisciplinary team.

The major concern is the reintroduction of the initial disease through malignant cells located in grafted ovarian fragments. In our project, only patients for whom the center's multidisciplinary team and the steering committee give approval are potential candidates for autograft. This agreement takes into account the advancement of techniques evaluating residual disease at the ovarian level.

Furthermore, a study named QUALIGRAFT17 is being carried out in parallel to the DATOR protocol. QUALIGRAFT17 aims to implement complementary analyses to better assess the quality of the grafts and the risk of reintroducing malignant cells. These analyses are performed on fragments of ovarian cortex specifically reserved for the study. A first important result was achieved with the validation of multicolor flow cytometry (MFC) as a method to detect ovarian residual disease in acute lymphoblastic leukemia $[96,97]$. Hitherto, MFC was a customary method to identify persisting leukemic cells in blood or bone marrow [101]. Our aim is the transfer of this method to other neoplastic pathologies. Another part of this project plans to develop a functional method of qualification consisting of the identification of cells expressing markers of endothelial cells or endothelial progenitors and the assessment of the quality of the stromal cells. This functional qualification and MFC will improve the management of patients for whom risk-free ovarian autograft is possible.

\section{Conclusions}

Data on autotransplantation after cryopreservation of ovarian tissue are increasingly encouraging, regarding both its efficacy and its safety. The results produced so far by the DATOR study are in line with such data and thus justify pursuit of this program. Our study will provide important and novel information, especially regarding early development of children born after OTC. 


\section{Acknowledgments}

This project is funded by a Young Researcher grant from the University Hospital of Besancon, France. The DATOR Group consists of Frédérique Dijoud, Germain Agnani, Pierre-Simon Rorhlich, Christophe Piguet, Brigitte Mignot, Eric Deconink, Christophe Borg, Francine Arbez Gindre, Paul Barrière, Patrick Bastit, Julie Blessmann Roset, Frédérique Carre Pigeon, Blandine Courbière, Christine Decanter, Marie-Catherine Diligent, Olivier Graesslin, Aurore Guennifey, Sylviane Hennebicq, Claude Hocke, Pascale Hoffmann, Isabelle Koscinski, Florence Leperlier, Brigitte Leroy, Loïc Marpeau, Catherine Metzler Guillemain, Aline Papaxanthos, Jean Parinaud, Jean-Christophe Pech, Anne Perdrix, Olivier Pirrello, Marius Teletin, Pascal Piver, Benoît Resch, Nathalie Rives, Jacques Villière, Denis Vinatier, Annie Zaccabri, Roger Leandri, Carole Fajau Prevot, Florence Eustache, Michael Grynberg, Rajeev Ramanah, Florence Brugnon, Anne-Sophie Greneau, Elodie Adda Herzog, Valérie Scarabin Carre, Nelly Achour Frydman, Pascale Lagre, Beatrice Delepine, Ghassan Harika, Rachel Levy, Nathalie Chabbert Buffet, Marcos Ballester, Cécile Mezan de Malartic, Bénédicte Paillusson, and Florence Boitrelle.

\section{Conflicts of Interest}

None declared.

\section{References}

1. Croucher C, Whelan JS, Møller H, Davies EA. Trends in the incidence and survival of cancer in teenagers and young adults: regional analysis for South East England 1960-2002. Clin Oncol (R Coll Radiol) 2009 Jun;21(5):417-424. [doi: 10.1016/j.clon.2009.02.006] [Medline: 19375901]

2. Aben KK, van Gaal C, van Gils NA, van der Graaf WT, Zielhuis GA. Cancer in adolescents and young adults (15-29 years): a population-based study in the Netherlands 1989-2009. Acta Oncol 2012 Sep;51(7):922-933. [doi: 10.3109/0284186X.2012.705891] [Medline: 22934554]

3. Cancer Research UK. Young People's Cancers Statistics URL: http://www.cancerresearchuk.org/health-professional/ cancer-statistics/teenagers-and-young-adults-cancers [accessed 2018-10-24]

4. Desandes E, Lacour B, Sommelet D, Danzon A, Delafosse P, Grosclaude P, et al. Cancer survival among adolescents in France. Eur J Cancer 2006 Feb;42(3):403-409. [doi: 10.1016/j.ejca.2005.07.035] [Medline: 16386892]

5. Jemal A, Siegel R, Ward E, Hao Y, Xu J, Murray T, et al. Cancer statistics, 2008. CA Cancer J Clin 2008;58(2):71-96 [FREE Full text] [doi: 10.3322/CA.2007.0010] [Medline: 18287387$]$

6. Ries LA, Melbert D, Krapcho M, Stinchcomb DG, Howlader N, Horner MJ, et al. SEER - National Cancer Institute. 2008. SEER Cancer Statistics Review, 1975-2005 URL: https://seer.cancer.gov/archive/csr/1975 2005/[accessed: [accessed 2018-11-13]

7. de Angelis R, Sant M, Coleman MP, Francisci S, Baili P, Pierannunzio D, et al. Cancer survival in Europe 1999-2007 by country and age: results of EUROCARE--5-a population-based study. Lancet Oncol 2014 Jan;15(1):23-34. [doi: 10.1016/S1470-2045(13)70546-1] [Medline: 24314615]

8. Levine JM, Kelvin JF, Quinn GP, Gracia CR. Infertility in reproductive-age female cancer survivors. Cancer 2015 May 15;121(10):1532-1539 [FREE Full text] [doi: 10.1002/cncr.29181] [Medline: 25649243]

9. Siegel RL, Miller KD, Jemal A. Cancer statistics, 2019. CA Cancer J Clin 2019 Jan;69(1):7-34 [FREE Full text] [doi: 10.3322/caac.21551] [Medline: $\underline{30620402]}$

10. Meirow D, Nugent D. The effects of radiotherapy and chemotherapy on female reproduction. Hum Reprod Update 2001;7(6):535-543. [doi: 10.1093/humupd/7.6.535] [Medline: 11727861]

11. Larsen EC, Müller J, Schmiegelow K, Rechnitzer C, Andersen AN. Reduced ovarian function in long-term survivors of radiation- and chemotherapy-treated childhood cancer. J Clin Endocrinol Metab 2003 Nov;88(11):5307-5314. [doi: 10.1210/jc.2003-030352] [Medline: 14602766]

12. Donnez J, Martinez-Madrid B, Jadoul P, van Langendonckt A, Demylle D, Dolmans MM. Ovarian tissue cryopreservation and transplantation: a review. Hum Reprod Update 2006;12(5):519-535. [doi: 10.1093/humupd/dml032] [Medline: 16849817]

13. Lie Fong S, Laven JS, Hakvoort-Cammel FG, Schipper I, Visser JA, Themmen AP, et al. Assessment of ovarian reserve in adult childhood cancer survivors using anti-Müllerian hormone. Hum Reprod 2009 Apr;24(4):982-990. [doi: 10.1093/humrep/den487] [Medline: 19153092]

14. Thomas-Teinturier C, Allodji RS, Svetlova E, Frey M, Oberlin O, Millischer A, et al. Ovarian reserve after treatment with alkylating agents during childhood. Hum Reprod 2015 Jun;30(6):1437-1446. [doi: 10.1093/humrep/dev060] [Medline: 25801499]

15. Donnez J, Bassil S. Indications for cryopreservation of ovarian tissue. Hum Reprod Update 1998;4(3):248-259. [doi: 10.1093/humupd/4.3.248] [Medline: 9741709]

16. Charpentier AM, Chong AL, Gingras-Hill G, Ahmed S, Cigsar C, Gupta AA, et al. Anti-Müllerian hormone screening to assess ovarian reserve among female survivors of childhood cancer. J Cancer Surviv 2014 Dec;8(4):548-554. [doi: 10.1007/s11764-014-0364-4] [Medline: 24810980]

17. Schover LR. Sexuality and fertility after cancer. Hematology Am Soc Hematol Educ Program 2005(1):523-527. [doi: 10.1182/asheducation-2005.1.523] [Medline: $\underline{16304430]}$ 
18. Molina JR, Barton DL, Loprinzi CL. Chemotherapy-induced ovarian failure: manifestations and management. Drug Saf 2005;28(5):401-416. [doi: 10.2165/00002018-200528050-00004] [Medline: 15853442]

19. Gracia CR, Sammel MD, Freeman E, Prewitt M, Carlson C, Ray A, et al. Impact of cancer therapies on ovarian reserve. Fertil Steril 2012 Jan;97(1):134-40.e1 [FREE Full text] [doi: 10.1016/j.fertnstert.2011.10.040] [Medline: 22137491]

20. Bedoschi G, Navarro PA, Oktay K. Chemotherapy-induced damage to ovary: mechanisms and clinical impact. Future Oncol 2016 Oct;12(20):2333-2344 [FREE Full text] [doi: 10.2217/fon-2016-0176] [Medline: 27402553]

21. Revel A, Laufer N. Protecting female fertility from cancer therapy. Mol Cell Endocrinol 2002 Feb 22;187(1-2):83-91. [doi: 10.1016/s0303-7207(01)00705-5] [Medline: 11988315]

22. Mattle V, Behringer K, Engert A, Wildt L. Female fertility after cytotoxic therapy--protection of ovarian function during chemotherapy of malignant and non-malignant diseases. Eur J Haematol Suppl 2005 Jul(66):77-82. [doi: 10.1111/j.1600-0609.2005.00459.x] [Medline: 16007873]

23. Behringer K, Wildt L, Mueller H, Mattle V, Ganitis P, van den Hoonaard B, et al. No protection of the ovarian follicle pool with the use of GnRH-analogues or oral contraceptives in young women treated with escalated BEACOPP for advanced-stage Hodgkin lymphoma. Final results of a phase II trial from the German Hodgkin study group. Ann Oncol 2010 Oct;21(10):2052-2060. [doi: 10.1093/annonc/mdq066] [Medline: 20305034]

24. Blumenfeld Z, Evron A. Preserving fertility when choosing chemotherapy regimens - the role of gonadotropin-releasing hormone agonists. Expert Opin Pharmacother 2015 May;16(7):1009-1020. [doi: 10.1517/14656566.2015.1031654] [Medline: 25826240]

25. Lambertini M, Ceppi M, Poggio F, Peccatori FA, Azim HA, Ugolini D, et al. Ovarian suppression using luteinizing hormone-releasing hormone agonists during chemotherapy to preserve ovarian function and fertility of breast cancer patients: a meta-analysis of randomized studies. Ann Oncol 2015 Dec;26(12):2408-2419. [doi: 10.1093/annonc/mdv374] [Medline: 26347105]

26. Salama M, Isachenko V, Isachenko E, Rahimi G, Mallmann P. Updates in preserving reproductive potential of prepubertal girls with cancer: systematic review. Crit Rev Oncol Hematol 2016 Jul;103:10-21. [doi: 10.1016/j.critrevonc.2016.04.002] [Medline: 27184425]

27. Demeestere I, Brice P, Peccatori FA, Kentos A, Dupuis J, Zachee P, et al. No evidence for the benefit of gonadotropin-releasing hormone agonist in preserving ovarian function and fertility in lymphoma survivors treated with chemotherapy: final long-term report of a prospective randomized trial. J Clin Oncol 2016 Aug 1;34(22):2568-2574. [doi: 10.1200/JCO.2015.65.8864] [Medline: 27217453]

28. Senra JC, Roque M, Talim MC, Reis FM, Tavares RL. Gonadotropin-releasing hormone agonists for ovarian protection during cancer chemotherapy: systematic review and meta-analysis. Ultrasound Obstet Gynecol 2018 Jan;51(1):77-86 [FREE Full text] [doi: 10.1002/uog.18934] [Medline: 29055060]

29. Sonigo C, Beau I, Grynberg M, Binart N. AMH prevents primordial ovarian follicle loss and fertility alteration in cyclophosphamide-treated mice. FASEB J 2019 Jan;33(1):1278-1287. [doi: 10.1096/fj.201801089R] [Medline: 30113879]

30. Kano M, Sosulski AE, Zhang L, Saatcioglu HD, Wang D, Nagykery N, et al. AMH/MIS as a contraceptive that protects the ovarian reserve during chemotherapy. Proc Natl Acad Sci U S A 2017 Feb 28;114(9):E1688-E1697 [FREE Full text] [doi: 10.1073/pnas.1620729114] [Medline: 28137855]

31. Lee HN, Chang EM. Primordial follicle activation as new treatment for primary ovarian insufficiency. Clin Exp Reprod Med 2019 Jun;46(2):43-49 [FREE Full text] [doi: 10.5653/cerm.2019.46.2.43] [Medline: 31181871]

32. Carter J, Rowland K, Chi D, Brown C, Abu-Rustum N, Castiel M, et al. Gynecologic cancer treatment and the impact of cancer-related infertility. Gynecol Oncol 2005 Apr;97(1):90-95. [doi: 10.1016/j.ygyno.2004.12.019] [Medline: 15790443]

33. Logan S, Perz J, Ussher JM, Peate M, Anazodo A. A systematic review of patient oncofertility support needs in reproductive cancer patients aged 14 to 45 years of age. Psychooncology 2018 Feb;27(2):401-409. [doi: 10.1002/pon.4502] [Medline: $\underline{28734119]}$

34. Logan S, Perz J, Ussher JM, Peate M, Anazodo A. Systematic review of fertility-related psychological distress in cancer patients: informing on an improved model of care. Psychooncology 2019 Jan;28(1):22-30. [doi: 10.1002/pon.4927] [Medline: 30460732]

35. Samuelsson A, Fuchs T, Simonsson B, Björkholm M. Successful pregnancy in a 28-year-old patient autografted for acute lymphoblastic leukemia following myeloablative treatment including total body irradiation. Bone Marrow Transplant 1993 Dec;12(6):659-660. [Medline: $\underline{8136750]}$

36. Schimmer AD, Quatermain M, Imrie K, Ali V, McCrae J, Stewart AK, et al. Ovarian function after autologous bone marrow transplantation. J Clin Oncol 1998 Jul;16(7):2359-2363. [doi: 10.1200/JCO.1998.16.7.2359] [Medline: 9667251]

37. Logan S, Perz J, Ussher J, Peate M, Anazodo A. Clinician provision of oncofertility support in cancer patients of a reproductive age: a systematic review. Psychooncology 2018 Mar;27(3):748-756. [doi: 10.1002/pon.4518] [Medline: 28762627]

38. Anderson RA, Wallace WH, Baird DT. Ovarian cryopreservation for fertility preservation: indications and outcomes. Reproduction 2008 Dec;136(6):681-689. [doi: 10.1530/REP-08-0097] [Medline: 18682546] 
39. Peccatori FA, Azim HA, Orecchia R, Hoekstra HJ, Pavlidis N, Kesic V, ESMO Guidelines Working Group. Cancer, pregnancy and fertility: ESMO clinical practice guidelines for diagnosis, treatment and follow-up. Ann Oncol 2013 Oct;24(Suppl 6):vi160-vi170. [doi: 10.1093/annonc/mdt199] [Medline: 23813932]

40. Köhler TS, Kondapalli LA, Shah A, Chan S, Woodruff TK, Brannigan RE. Results from the survey for preservation of adolescent reproduction (SPARE) study: gender disparity in delivery of fertility preservation message to adolescents with cancer. J Assist Reprod Genet 2011 Mar;28(3):269-277 [FREE Full text] [doi: 10.1007/s10815-010-9504-6] [Medline: 21110080]

41. Lambertini M, del Mastro L, Pescio MC, Andersen CY, Azim HA, Peccatori FA, et al. Cancer and fertility preservation: international recommendations from an expert meeting. BMC Med 2016 Jan 4;14:1 [FREE Full text] [doi: 10.1186/s12916-015-0545-7] [Medline: 26728489]

42. Condorelli M, Lambertini M, del Mastro L, Boccardo F, Demeestere I, Bober SL. Fertility, sexuality and cancer in young adult women. Curr Opin Oncol 2019 Jul;31(4):259-267. [doi: 10.1097/CCO.0000000000000540] [Medline: 30893151]

43. Anazodo A, Laws P, Logan S, Saunders C, Travaglia J, Gerstl B, et al. How can we improve oncofertility care for patients? A systematic scoping review of current international practice and models of care. Hum Reprod Update 2019 Mar 1;25(2):159-179 [FREE Full text] [doi: 10.1093/humupd/dmy038] [Medline: 30462263]

44. Oktay K, Harvey BE, Partridge AH, Quinn GP, Reinecke J, Taylor HS, et al. Fertility preservation in patients with cancer: ASCO clinical practice guideline update. J Clin Oncol 2018 Jul 1;36(19):1994-2001. [doi: 10.1200/JCO.2018.78.1914] [Medline: 29620997]

45. Winkler-Crepaz K, Böttcher B, Toth B, Wildt L, Hofer-Tollinger S. What is new in 2017? Update on fertility preservation in cancer patients. Minerva Endocrinol 2017 Dec;42(4):331-339. [doi: 10.23736/S0391-1977.17.02633-5] [Medline: 28322537]

46. Anderson RA, Wallace WH, Telfer EE. Ovarian tissue cryopreservation for fertility preservation: clinical and research perspectives. Hum Reprod Open 2017;2017(1):hox001 [FREE Full text] [doi: 10.1093/hropen/hox001] [Medline: 30895221]

47. Donnez J, Dolmans MM. Preservation of fertility in females with haematological malignancy. Br J Haematol 2011 Jul;154(2):175-184. [doi: 10.1111/j.1365-2141.2011.08723.x] [Medline: 21564077]

48. Poirot C, Martelli H, Lichtblau I, Dhedin N, Abirached F, Faraguet C, et al. [Female fertility preservation before sterilizing treatment: contribution of ovarian tissue cryopreservation]. J Gynecol Obstet Biol Reprod (Paris) 2002 Dec;31(8):717-723 [FREE Full text] [Medline: 12592191]

49. Gosden RG, Baird DT, Wade JC, Webb R. Restoration of fertility to oophorectomized sheep by ovarian autografts stored at -196 degrees C. Hum Reprod 1994 Apr;9(4):597-603. [doi: 10.1093/oxfordjournals.humrep.a138556] [Medline: 8046009]

50. Fauque P, Ben Amor A, Joanne C, Agnani G, Bresson JL, Roux C. Use of trypan blue staining to assess the quality of ovarian cryopreservation. Fertil Steril 2007 May;87(5):1200-1207. [doi: 10.1016/j.fertnstert.2006.08.115] [Medline: 17307173]

51. Kagawa N, Silber S, Kuwayama M. Successful vitrification of bovine and human ovarian tissue. Reprod Biomed Online 2009 Apr;18(4):568-577. [doi: 10.1016/S1472-6483(10)60136-8] [Medline: 19401001]

52. Silber S, Kagawa N, Kuwayama M, Gosden R. Duration of fertility after fresh and frozen ovary transplantation. Fertil Steril 2010 Nov;94(6):2191-2196. [doi: 10.1016/j.fertnstert.2009.12.073] [Medline: 20171622]

53. Nikiforov D, Russo V, Nardinocchi D, Bernabò N, Mattioli M, Barboni B. Innovative multi-protectoral approach increases survival rate after vitrification of ovarian tissue and isolated follicles with improved results in comparison with conventional method. J Ovarian Res 2018 Aug 7;11(1):65 [FREE Full text] [doi: 10.1186/s13048-018-0437-5] [Medline: 30086787]

54. Abir R, Nitke S, Ben-Haroush A, Fisch B. In vitro maturation of human primordial ovarian follicles: clinical significance, progress in mammals, and methods for growth evaluation. Histol Histopathol 2006 Aug;21(8):887-898. [doi: 10.14670/HH-21.887] [Medline: 16691541]

55. Smitz JE, Thompson JG, Gilchrist RB. The promise of in vitro maturation in assisted reproduction and fertility preservation. Semin Reprod Med 2011 Jan;29(1):24-37. [doi: 10.1055/s-0030-1268701] [Medline: 21207332]

56. Telfer EE, McLaughlin M. Strategies to support human oocyte development in vitro. Int J Dev Biol 2012;56(10-12):901-907 [FREE Full text] [doi: 10.1387/ijdb.130001et] [Medline: 23417412]

57. Telfer EE, Zelinski MB. Ovarian follicle culture: advances and challenges for human and nonhuman primates. Fertil Steril 2013 May;99(6):1523-1533 [FREE Full text] [doi: 10.1016/j.fertnstert.2013.03.043] [Medline: 23635350]

58. Zhai J, Yao G, Dong F, Bu Z, Cheng Y, Sato Y, et al. In vitro activation of follicles and fresh tissue auto-transplantation in primary ovarian insufficiency patients. J Clin Endocrinol Metab 2016 Nov;101(11):4405-4412 [FREE Full text] [doi: 10.1210/jc.2016-1589] [Medline: 27571179]

59. Khalili MA, Shahedi A, Ashourzadeh S, Nottola SA, Macchiarelli G, Palmerini MG. Vitrification of human immature oocytes before and after in vitro maturation: a review. J Assist Reprod Genet 2017 Nov;34(11):1413-1426 [FREE Full text] [doi: 10.1007/s10815-017-1005-4] [Medline: 28822010]

60. Fasano G, Dechène J, Antonacci R, Biramane J, Vannin AS, van Langendonckt A, et al. Outcomes of immature oocytes collected from ovarian tissue for cryopreservation in adult and prepubertal patients. Reprod Biomed Online 2017 Jun;34(6):575-582. [doi: 10.1016/j.rbmo.2017.03.007] [Medline: 28365199] 
61. Bertoldo MJ, Walters KA, Ledger WL, Gilchrist RB, Mermillod P, Locatelli Y. In-vitro regulation of primordial follicle activation: challenges for fertility preservation strategies. Reprod Biomed Online 2018 May;36(5):491-499. [doi: 10.1016/j.rbmo.2018.01.014] [Medline: 29503209]

62. McLaughlin M, Albertini DF, Wallace WH, Anderson RA, Telfer EE. Metaphase II oocytes from human unilaminar follicles grown in a multi-step culture system. Mol Hum Reprod 2018 Mar 1;24(3):135-142. [doi: 10.1093/molehr/gay002] [Medline: 29390119]

63. Mouloungui E, Zver T, Roux C, Amiot C. A protocol to isolate and qualify purified human preantral follicles in cases of acute leukemia, for future clinical applications. J Ovarian Res 2018 Jan 5;11(1):4 [FREE Full text] [doi: 10.1186/s13048-017-0376-6] [Medline: 29304838]

64. Chiti MC, Donnez J, Amorim CA, Dolmans MM. From isolation of human ovarian follicles to the artificial ovary: tips and tricks. Minerva Ginecol 2018 Aug;70(4):444-455. [doi: 10.23736/S0026-4784.18.04231-4] [Medline: 29644331]

65. Paulini F, Vilela JM, Chiti MC, Donnez J, Jadoul P, Dolmans MM, et al. Survival and growth of human preantral follicles after cryopreservation of ovarian tissue, follicle isolation and short-term xenografting. Reprod Biomed Online 2016 Sep;33(3):425-432. [doi: 10.1016/j.rbmo.2016.05.003] [Medline: 27210771]

66. Amorim CA, Shikanov A. The artificial ovary: current status and future perspectives. Future Oncol 2016 Oct;12(20):2323-2332. [doi: 10.2217/fon-2016-0202] [Medline: 27396310]

67. Cho E, Kim YY, Noh K, Ku SY. A new possibility in fertility preservation: the artificial ovary. J Tissue Eng Regen Med 2019 May 6 (epub ahead of print). [doi: 10.1002/term.2870] [Medline: $\underline{31062444]}$

68. Jensen AK, Kristensen SG, Macklon KT, Jeppesen JV, Fedder J, Ernst E, et al. Outcomes of transplantations of cryopreserved ovarian tissue to 41 women in Denmark. Hum Reprod 2015 Dec;30(12):2838-2845. [doi: 10.1093/humrep/dev230] [Medline: 26443605]

69. Hudson JN, Stanley NB, Nahata L, Bowman-Curci M, Quinn GP. New promising strategies in oncofertility. Expert Rev Qual Life Cancer Care 2017;2(2):67-78 [FREE Full text] [doi: 10.1080/23809000.2017.1308808] [Medline: 28959743]

70. Demeestere I, Simon P, Emiliani S, Delbaere A, Englert Y. Orthotopic and heterotopic ovarian tissue transplantation. Hum Reprod Update 2009;15(6):649-665 [FREE Full text] [doi: 10.1093/humupd/dmp021] [Medline: 19474206]

71. Kondapalli LA. Ovarian tissue cryopreservation and transplantation. In: Gracia C, Woodruff TK, editors. Oncofertility Medical Practice: Clinical Issues and Implementation. New York: Springer; 2012:63-75.

72. Soares M, Dolmans MM, Donnez J. Heterotopic ovarian tissue transplantation. In: Suzuki N, Donnez J, editors. Gonadal Tissue Cryopreservation in Fertility Preservation. Tokyo, Japan: Springer; 2016:105-123.

73. Donfack NJ, Alves KA, Araújo VR, Cordova A, Figueiredo JR, Smitz J, et al. Expectations and limitations of ovarian tissue transplantation. Zygote 2017 Aug;25(4):391-403. [doi: 10.1017/S0967199417000338] [Medline: 28766468]

74. Oktay K, Karlikaya G. Ovarian function after transplantation of frozen, banked autologous ovarian tissue. N Engl J Med 2000 Jun 22;342(25):1919. [doi: 10.1056/NEJM200006223422516] [Medline: 10877641]

75. Radford JA, Lieberman BA, Brison DR, Smith AR, Critchlow JD, Russell SA, et al. Orthotopic reimplantation of cryopreserved ovarian cortical strips after high-dose chemotherapy for Hodgkin's lymphoma. Lancet 2001 Apr 14;357(9263):1172-1175. [doi: 10.1016/s0140-6736(00)04335-x] [Medline: 11323045]

76. Oktay K, Buyuk E, Veeck L, Zaninovic N, Xu K, Takeuchi T, et al. Embryo development after heterotopic transplantation of cryopreserved ovarian tissue. Lancet 2004 Mar 13;363(9412):837-840. [doi: 10.1016/S0140-6736(04)15728-0] [Medline: $\underline{15031026]}$

77. Donnez J, Dolmans MM, Demylle D, Jadoul P, Pirard C, Squifflet J, et al. Livebirth after orthotopic transplantation of cryopreserved ovarian tissue. Lancet 2004;364(9443):1405-1410. [doi: 10.1016/S0140-6736(04)17222-X] [Medline: $\underline{15488215}$ ]

78. Donnez J, Dolmans MM. Fertility preservation in women. N Engl J Med 2017 Oct 26;377(17):1657-1665. [doi: 10.1056/NEJMra1614676] [Medline: 29069558]

79. Jensen AK, Macklon KT, Fedder J, Ernst E, Humaidan P, Andersen CY. 86 successful births and 9 ongoing pregnancies worldwide in women transplanted with frozen-thawed ovarian tissue: focus on birth and perinatal outcome in 40 of these children. J Assist Reprod Genet 2017 Mar;34(3):325-336 [ [FREE Full text] [doi: 10.1007/s10815-016-0843-9] [Medline: 28028773]

80. Donnez J, Dolmans MM, Pellicer A, Diaz-Garcia C, Serrano MS, Schmidt KT, et al. Restoration of ovarian activity and pregnancy after transplantation of cryopreserved ovarian tissue: a review of 60 cases of reimplantation. Fertil Steril 2013 May;99(6):1503-1513. [doi: 10.1016/j.fertnstert.2013.03.030] [Medline: 23635349]

81. Stoop D, Cobo A, Silber S. Fertility preservation for age-related fertility decline. Lancet 2014 Oct 4;384(9950):1311-1319. [doi: 10.1016/S0140-6736(14)61261-7] [Medline: 25283572]

82. Donnez J, Dolmans MM. Ovarian cortex transplantation: 60 reported live births brings the success and worldwide expansion of the technique towards routine clinical practice. J Assist Reprod Genet 2015 Aug;32(8):1167-1170 [FREE Full text] [doi: 10.1007/s10815-015-0544-9] [Medline: 26210678]

83. Dittrich R, Hackl J, Lotz L, Hoffmann I, Beckmann MW. Pregnancies and live births after 20 transplantations of cryopreserved ovarian tissue in a single center. Fertil Steril 2015 Feb;103(2):462-468. [doi: 10.1016/j.fertnstert.2014.10.045] [Medline: 25487750] 
84. Meirow D, Ra'anani H, Shapira M, Brenghausen M, Chaim SD, Aviel-Ronen S, et al. Transplantations of frozen-thawed ovarian tissue demonstrate high reproductive performance and the need to revise restrictive criteria. Fertil Steril 2016 Aug;106(2):467-474. [doi: 10.1016/j.fertnstert.2016.04.031] [Medline: 27181924]

85. van der Ven H, Liebenthron J, Beckmann M, Toth B, Korell M, Krüssel J, et al. Ninety-five orthotopic transplantations in 74 women of ovarian tissue after cytotoxic treatment in a fertility preservation network: tissue activity, pregnancy and delivery rates. Hum Reprod 2016 Sep;31(9):2031-2041. [doi: 10.1093/humrep/dew165] [Medline: 27378768]

86. Jadoul P, Guilmain A, Squifflet J, Luyckx M, Votino R, Wyns C, et al. Efficacy of ovarian tissue cryopreservation for fertility preservation: lessons learned from 545 cases. Hum Reprod 2017 May 1;32(5):1046-1054. [doi: 10.1093/humrep/dex040] [Medline: 28333228]

87. Diaz-Garcia C, Domingo J, Garcia-Velasco JA, Herraiz S, Mirabet V, Iniesta I, et al. Oocyte vitrification versus ovarian cortex transplantation in fertility preservation for adult women undergoing gonadotoxic treatments: a prospective cohort study. Fertil Steril 2018 Mar;109(3):478-85.e2. [doi: 10.1016/j.fertnstert.2017.11.018] [Medline: 29428307]

88. Gellert SE, Pors SE, Kristensen SG, Bay-Bjørn AM, Ernst E, Andersen CY. Transplantation of frozen-thawed ovarian tissue: an update on worldwide activity published in peer-reviewed papers and on the Danish cohort. J Assist Reprod Genet 2018 Apr;35(4):561-570 [FREE Full text] [doi: 10.1007/s10815-018-1144-2] [Medline: 29497953]

89. Roux C, Amiot C, Agnani G, Aubard Y, Rohrlich PS, Piver P. Live birth after ovarian tissue autograft in a patient with sickle cell disease treated by allogeneic bone marrow transplantation. Fertil Steril 2010 May 1;93(7):2413.e15-2413.e19. [doi: 10.1016/j.fertnstert.2009.12.022] [Medline: 20117783]

90. Accueil | Légifrance, Le Service Public De La Diffusion Du Droit. 2017. Arrêté Du 30 Juin 2017 Modifiant L'arrêté Du 11 Avril 2008 Modifié Relatif Aux Règles De Bonnes Pratiques Cliniques Et Biologiques D'assistance Médicale À La Procréation URL: https://www.legifrance.gouv.fr/affichTexte.do?cidTexte=JORFTEXT000035138350\&categorieLien=id [accessed 2019-08-22]

91. ISFP Practice Committee, Kim SS, Donnez J, Barri P, Pellicer A, Patrizio P, et al. Recommendations for fertility preservation in patients with lymphoma, leukemia, and breast cancer. J Assist Reprod Genet 2012 Jun;29(6):465-468 [FREE Full text] [doi: 10.1007/s10815-012-9786-y] [Medline: 22648282]

92. Dolmans MM, Masciangelo R. Risk of transplanting malignant cells in cryopreserved ovarian tissue. Minerva Ginecol 2018 Aug;70(4):436-443. [doi: 10.23736/S0026-4784.18.04233-8] [Medline: 29644333]

93. Meirow D, Hardan I, Dor J, Fridman E, Elizur S, Ra'anani H, et al. Searching for evidence of disease and malignant cell contamination in ovarian tissue stored from hematologic cancer patients. Hum Reprod 2008 May;23(5):1007-1013. [doi: 10.1093/humrep/den055] [Medline: 18344563]

94. Greve T, Clasen-Linde E, Andersen MT, Andersen MK, Sørensen SD, Rosendahl M, et al. Cryopreserved ovarian cortex from patients with leukemia in complete remission contains no apparent viable malignant cells. Blood 2012 Nov 22;120(22):4311-4316 [FREE Full text] [doi: 10.1182/blood-2012-01-403022] [Medline: 22709693]

95. Asadi-Azarbaijani B, Sheikhi M, Nurmio M, Tinkanen H, Juvonen V, Dunkel L, et al. Minimal residual disease of leukemia and the quality of cryopreserved human ovarian tissue in vitro. Leuk Lymphoma 2016;57(3):700-707. [doi: 10.3109/10428194.2015.1065980] [Medline: 26122194]

96. Amiot C, Angelot-Delettre F, Zver T, Alvergnas-Vieille M, Saas P, Garnache-Ottou F, et al. Minimal residual disease detection of leukemic cells in ovarian cortex by eight-color flow cytometry. Hum Reprod 2013 Aug;28(8):2157-2167. [doi: 10.1093/humrep/det126] [Medline: 23633552]

97. Zver T, Alvergnas-Vieille M, Garnache-Ottou F, Roux C, Amiot C. A new method for evaluating the risk of transferring leukemic cells with transplanted cryopreserved ovarian tissue. J Assist Reprod Genet 2015 Aug;32(8):1263-1266 [FREE Full text] [doi: 10.1007/s10815-015-0512-4] [Medline: 26139154]

98. Lotz L, Montag M, van der Ven H, von Wolff M, Mueller A, Hoffmann I, et al. Xenotransplantation of cryopreserved ovarian tissue from patients with ovarian tumors into SCID mice--no evidence of malignant cell contamination. Fertil Steril 2011 Jun 30;95(8):2612-4.e1. [doi: 10.1016/j.fertnstert.2011.05.003] [Medline: 21621205]

99. Meyer LH, Debatin KM. Diversity of human leukemia xenograft mouse models: implications for disease biology. Cancer Res 2011 Dec 1;71(23):7141-7144 [FREE Full text] [doi: 10.1158/0008-5472.CAN-11-1732] [Medline: 22088964]

100. Accueil | Légifrance, Le Service Public De La Diffusion Du Droit. 2019. Arrêté Du 11 Avril 2008 Relatif Aux Règles De Bonnes Pratiques Cliniques Et Biologiques D'assistance Médicale À La Procréation URL: https://www.legifrance.gouv.fr/ affichTexte.do?cidTexte=JORFTEXT000018829426 [accessed 2019-08-22]

101. Campana D, Coustan-Smith E. Detection of minimal residual disease in acute leukemia by flow cytometry. Cytometry 1999 Aug 15;38(4):139-152. [doi: 10.1002/cyto.b.21766] [Medline: 10440852]

\section{Abbreviations}

ABM: agence de BioMedecine (BioMedicine agency)

AMH: anti-Müllerian hormone

ART: assisted reproductive technology

DATOR: Development of Ovarian Tissue Autograft in Order to Restore Ovarian Function 
FSH: follicle-stimulating hormone

LH: luteinizing hormone

MFC: multicolor flow cytometry

OTC: ovarian tissue cryopreservation

PERIDATOR: Prospective Cohort of Patients Candidates for Ovarian Tissue Autograft

Edited by G Eysenbach; submitted 28.11.18; peer-reviewed by E Antwi, MM Dolmans, K Kawamura; comments to author 29.04.19;

revised version received 24.06.19; accepted 21.07.19; published 30.09.19

Please cite as:

Pretalli JB, Frontczak Franck S, Pazart L, Roux C, Amiot C, DATOR Group

Development of Ovarian Tissue Autograft to Restore Ovarian Function: Protocol for a French Multicenter Cohort Study

JMIR Res Protoc 2019;8(9):e12944

URL: https://www.researchprotocols.org/2019/9/e12944

doi: $\underline{10.2196 / 12944}$

PMID: 31573931

CJean-Baptiste Pretalli, Sophie Frontczak Franck, Lionel Pazart, Christophe Roux, Clotilde Amiot, DATOR Group. Originally published in JMIR Research Protocols (http://www.researchprotocols.org), 30.09.2019 This is an open-access article distributed under the terms of the Creative Commons Attribution License (https://creativecommons.org/licenses/by/4.0/), which permits unrestricted use, distribution, and reproduction in any medium, provided the original work, first published in JMIR Research Protocols, is properly cited. The complete bibliographic information, a link to the original publication on http://www.researchprotocols.org, as well as this copyright and license information must be included. 